\title{
Disinfection of Water Systems in Accordance with Eu Directives on Health and Safety in Working Environments: Use of A Technologically Advanced $\mathrm{ClO}_{2}$ Generator
}

\author{
Roberto Lombardi ${ }^{1 *}$, Vincenzo Romano Spica ${ }^{2}$, Alberto Firenze ${ }^{3}$ and Massimo Clementi ${ }^{4}$ \\ ${ }^{1}$ Department of Technological Innovations, INAIL (National Institute for Insurance against Accidents at Work), Rome \\ ${ }^{2}$ Department of Human and Health Sciences, University of Rome "Foro Italico", Rome
}

${ }^{3}$ Presidio Azienda Ospedaliera Policlinico "Paolo Giaccone", Palermo

${ }^{4}$ Microbiology and Virology Laboratory University Vita Salute San Raffaele, Milan

*Corresponding author: Roberto Lombardi, Department of Technological Innovations INAIL, Research Centre, Via Fontana Candida

100040 Monteporzio Catone (Rm), Italy

\section{ARTICLE INFO}

Received: 幽 September 15, 2020

Published: 蔧 December 03, 2020

Citation: Roberto Lombardi, Vincenzo Romano Spica, Alberto Firenze, Massimo Clementi. Disinfection of Water Systems in Accordance with Eu Directives on Health and Safety in Working Environments: Use of A Technologically Advanced $\mathrm{ClO}_{2}$ Generator. Biomed J Sci \& Tech Res 32(2)-2020. BJSTR. MS.ID.005235.

Keywords: Disinfection; Biological Agents; Legionella; $\mathrm{ClO}_{2}$ Generator; Community Legislation

Abbreviations: ECDC: European Centre for Disease Prevention and Control; EU: European Union; UFC: Colony Forming Units; MPN: Most Probable Number; UG: Genomic Units

\begin{abstract}
It is currently of great interest to develop prevention systems for the management of the risk of microbial contamination of water in buildings of various types in which work is done. In this regard, international organizations have drawn up reference guidelines and in the EU countries specific legislative provisions indicated in the EU directives must be observed. A pilot system, copying a building pipeline, was designed, and developed to test water treatments with a $\mathrm{ClO}_{2}$ generator. Chemical and physical parameters were monitored in real time and the effectiveness of disinfection was tested on several microorganisms, focusing on Legionella. The scale plant reached steady state within 24 hours and maintained equilibrium, showing stability to chemical and physical parameters. Simulations showed disinfection efficacy for different contaminations $(>1,000,000 \mathrm{CFU})$ under water system conditions. Escherichia coli counts and other indicators showed a 99.999\% reduction within 15 minutes while Legionella and other environmental species showed a $99.999 \%$ reduction within 30 minutes. In addition, the system proved to be effective on complex microflora and other species and allowed to demonstrate adherence to the regulatory framework and legislative requirements (italian legislation's accepte of EU directives on health and safety at work D.lgs. [1]. And with particular reference to the European Directive [2] and European Parliament's Directive [3].
\end{abstract}

The study model can be easily extended to simulate particular risk situations, verifying for each of them the effective compliance with current legislation. This pilot model can be a feasible support in validating or comparing alternative solutions and new technologies for disinfection of water.

\section{Introduction}

One of the main problems in the management of water in buildings is the risk of legionnaires' disease for users and workers. In fact, legionellosis is currently considered a global problem. The WHO points out those $10-15$ cases/1,000,000 inhabitants are reported each year in Europe, Australia and the USA (www.who.int/ en/news-room/fact-sheets/detail/legionellosis December 2016).

The bacterium responsible is Legionella pneumophila. A chlorine dioxide generator is used in the pilot water treatment plant (Figure 1). To test the effectiveness of the technologically advanced LOTUS AIR [4-20] generator a pilot system has been used. The use of chlorine dioxide in water disinfection has been shown to be more effective than chlorine against bacteria, algae, fungi, and viruses. Its 
action is not aggressive against pipes and has a longer lasting effect and at a wider range from the injection point, making it possible to treat entire hydraulic systems even using small quantities of product. There are also no potentially carcinogenic disinfection byproducts, unlike chlorine, and for all these reasons its use is ecological and also suitable for drinking water treatment. As well as to combat legionella in hospitals, retirement homes, hotels, and school buildings. According to data provided by the European Centre for Disease Prevention and Control (ECDC) in 2017, between the countries of the European Union (EU) and the European Economic Area (EEA), 9238 cases of legionella were reported, with a notification rate of 1.8 per 100 thousand inhabitants, an increase compared to previous years (in 2013 it was 1.2 per 100 thousand inhabitants).

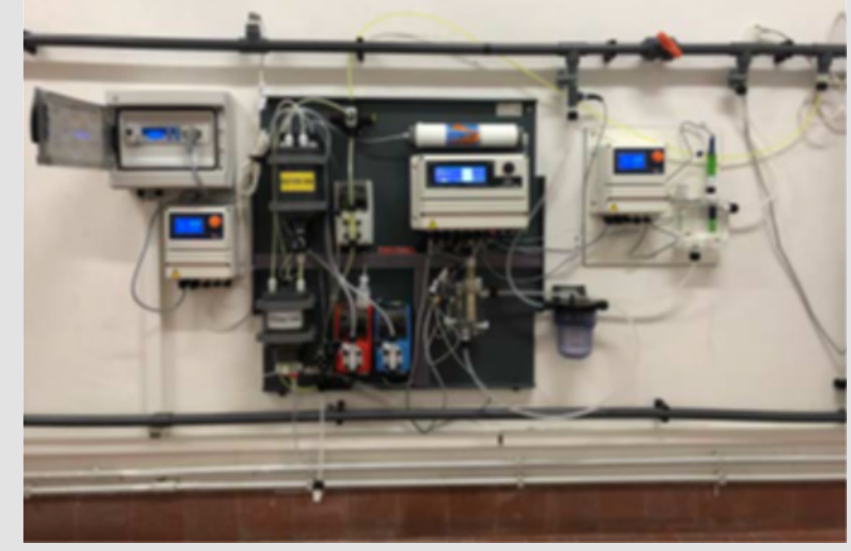

Figure 1: Pilot plant where the experimental tests were carried out.

France, Germany, Italy, and Spain together recorded $68 \%$ of cases notified in 2017.The majority of cases (69\%) are of EU origin, $21 \%$ are associated with travel and $8 \%$ are of nosocomial origin. $91 \%$ of cases are over 45 years of age and the male-to-female ratio is 2.4 to 1 . In addition, the lethality rate in 2017 was $8 \%$, a value comparable to that of previous years. Laboratory analysis identified L. pneumophila serogroup 1 as the most frequent aetiological agent (present in $79 \%$ of cases confirmed in culture). https://www.epicentro.iss.it/legionellosi/epidemiologia-europa The incidence of legionellosis in Italy in 2017 was 33.2 cases per million inhabitants, a slight increase compared to last year $(25.1 / 1,000,000)$, as was the absolute number of cases. However, there is a North-South gradient with values equal to 50.1 cases per million in the North, 35.1 per million in the Centre and 9.7 per million in the South [21-32]. In 2017 there were 124 (6.2 of the total number of reported nosocomial cases), of which 50 (40.3\%) of confirmed nosocomial origin and $74(59.7 \%)$ of probable nosocomial origin. Of the nosocomial cases, $73 \%$ were notified by Lombardia, Emilia-Romagna, Lazio, Provincia Autonoma di Trento and Piemonte. In all cases diagnosed by culture examination, the etiological agent responsible for the disease was L. pneumophila [33-40]. https://www.epicentro.iss.it/legionellosi/epidemiologia-italia The prevention measures to be implemented are those appropriate to prevent the growth and development of the bacterium. In particular, all innovative and technologically advanced procedures and methods for cleaning and disinfecting the water system, any related device, cooling towers, evaporative towers, swimming pools and whirlpools must be carefully considered. In the field of health protection from infectious agents, it is necessary to consider, among the most important collective prevention-protection interventions, the disinfection activity that can be carried out through different methods, for example through manual procedures or using various types of equipment. Disinfection, which is very important for health protection, must be effective against all the biological agents that constitute the source of the infection or infections [41-60]. It is necessary to use disinfection methods that carefully consider the necessary contact times of the different substrates and possible interfering means, in which the infectious agents are present, since the microbicidal properties may be insufficient, cancelled out or greatly reduced. At the same time, it is necessary to be careful in the choice of formulations and compounds to be used, also evaluating the characteristics of toxicity for exposed subjects in relation to the concentrations of use.

Moreover, according to Italian legislation, in the case of disinfection of water distributed by the water system, it is important to avoid the formation of chemical compounds capable of causing exposure toxicity and/or making the water unsuitable for human consumption (Legislative Decree 31/2001 and subsequent amendments and additions (Legislative Decree 31/2001 and subsequent amendments and integrations. The choice of the disinfection method involves a careful priority selection of the compounds to be used also in the case of equipment that must use these active ingredients or formulations in order to comply with the safety measures established by the legislation in force. This legislation in Italy is Legislative Decree 81/2008 and subsequent amendments and additions (Consolidation Act on Health and Safety at Work - Implementation of Article 1 of Law no. 123 of 3 August 2007 on the protection of health and safety at work, transposition into Italian law of EU directives on health and safety at work) and in particular the provisions of Title X (transposition of Directive $54 / 2000$ EC and subsequent amendments and additions) and Title I (transposition of Directive 391/89 EC and subsequent amendments and additions). In this regard, it is necessary to carefully consider the provisions of Article 15, paragraph 1, letter c) of the above-mentioned Title I, "elimination of risks in relation to knowledge acquired on the basis of technical progress and, where this is not possible, their reduction to a minimum", as well as the provisions of Art.

18 paragraph 1 letter $\mathrm{z}$ )" the employer .......updates the measures of prevention ........., that is, in relation to the degree of evolution of the technique of prevention and protection" and what is further highlighted by the jurisprudence of the sector [61-75]. In 
choosing the disinfection methodology, it is important to examine the technical/scientific documentation in which, as in the case under observation, it can be established the effectiveness against microbial agents that, if present in the water of a water system, may be able to cause damage to the health of individuals who may be in a condition of risk of exposure. From this examination derives therefore the possibility of verifying compliance with the requirements of the aforementioned legislation (Legislative Decree 81/2008 and subsequent amendments and integrations).

\section{Materials and Methods}

A pilot plant has been designed and developed with a water circuit connecting to the chlorine dioxide generator mentioned above to verify the effectiveness of decontamination treatment from legionella and/or other pathogens. The study is carried out in the period 2017/ 2018.For the first experimental tests, September 2017 November 2017, both traditional methods, based on cultivation methods, and molecular tests related to the genetic analysis of bacterial DNA were used, using advanced techniques such as NGS (Next Generation Sequencing) applied to microflora DNA (mfDNA). The objective was to evaluate the disinfectant action of chlorine dioxide in an experimental pilot plant powered by the $\mathrm{CIO}_{2}$ generator and the second experiment, carried out in May 2018, intended to verify the disinfectant action of Chlorine Dioxide on Legionella Specifically, these experimental tests were carried out using Legionella pneumophila, in order to verify the effectiveness of the disinfectant action of $\mathrm{ClO}_{2}$ in the "water" array, and in particular considering its application within a water system. The pilot plant allows the tests to be conducted in such a way as to detect all chemical, physical, and microbiological parameters. The observed data therefore assume a particularly relevant meaning and can be attributed in a highly significant way to the exclusive action of the disinfection system used, demonstrating its effectiveness.

For the microbiological analysis, in addition to the evaluation of the total microbial charge, the experimental tests reported here, have specifically considered bacteria indicators of faecal contamination (Escherichia coli, Enterococcus faecalis): using the official procedures for the microbiological analysis of water and in particular ISTISAN protocols and / or based on defined substrate technology (Idexx), widely adopted and approved by Italian and international institutions [76-85]. For molecular analysis, amplification techniques have been used starting from rDNA and products tested for electrophoresis, real-time PCR or through NGS using Illumina system. Quality controls have been systematically carried out for both classical and molecular methods, confirming the validity of the cultivation tests and/or the absence of inhibitory agents on the amplification reaction. The microbial content was expressed in UFC (Colony Forming Units), MPN (Most Probable Number) or UG (Genomic Units), depending on the method reported. In the second experimentation's phase, both traditional methods, based on traditional cultivation methods (Guidelines for the prevention and control of legionellosis', published in the Official Gazette of $5^{\text {th }}$ May 2000; 'Guidelines on Legionellosis for managers of tourist accommodation and spa facilities' and 'Guidelines for laboratories with microbiological diagnosis and environmental control of legionellosis' (Official Gazette no. 28 of 4 February 2005 and Official Gazette no. 29 of 5 February 2005).

The guidelines have been updated in the light of new scientific knowledge, with the technical-scientific support of the Istituto Superiore di Sanità and institutional experts in the field.) by measuring the Colony Forming Units (CUF), and innovative microbiological tests based on defined substrate technology aimed at the definition of the Most Probable Number (MPN), as well as molecular tests based on genetic analysis of bacterial DNA measured in Genomic Units (UG) by Real Time PCR, were taken into consideration. Evaluations were performed at zero time (T0), after inoculation from the moment of entry into circulation in the pilot plant (Tc) and after 5 minutes (T5) and then at 30 minutes (T30), in accordance with standard guidelines and protocols. Further tests at subsequent times were planned to verify the preservation of the disinfection efficacy over time even after repeated contamination, and in particular at 60 minutes (T60) and 20 hours (T20H).The experimental inoculations were performed by adapting standard protocols and UNI references, as previously described in the pilot unit for other experimental conditions, including tests on microbiological indicators, microflora assessments and other tests with Legionella simulating contamination conditions with high amounts of microorganisms and organic material. Samples were taken according to traditional procedures in the presence of sodium thiosulphate $\left(\mathrm{Na}_{2} \mathrm{~S}_{2} \mathrm{O}_{3}\right)$.

Quality controls were systematically performed at least in duplicate for both classical and molecular methods, confirming the validity of the culture tests and/or the absence of inhibitory agents on the amplification reaction [86-95]. Simulating steady state conditions of use in a water system, two independent inoculations ( $>109 \mathrm{CFU}$ ) were performed using ATCC strains of Legionella pneumophila on the pilot plant. The different tests were reproduced at least in duplicate. The chemical-physical parameters were collected using the specific test tubes included in the pilot unit. Microbiological measurements were expressed in UFCs (Colony Forming Units), MPNs (Most Probable Numbers) or UGs (Genomic Units), depending on the method used. The figure shows the data obtained by applying the current guidelines for the research of Legionella. Each evaluation was carried out in independent experiments and at least in duplicate for each of the expected sampling times (Appendix 1). These tests were performed on the pilot system through the introduction of particular improvements to control the different variables and monitor the main parameters in real time (online) during the experiment, including introduction of new sensors (eg. Chlorites, flow), modification of the recirculation and flow-rate systems with membrane pump, water heating with 
stainless steel exchanger at controlled temperature, elimination of dead limbs and other causes of stagnation or turbulence in the flow, increase in the volume of the system $(>50 \mathrm{~L})$, introduction of solutions to facilitate the picking and the inoculation (peristaltic pump and tank in series), in accordance with the needs of the experiment and safety for the operator.

In order to perform the experimental tests under stable and controlled conditions, the pilot plant had previously been brought to equilibrium and supervised continuously for one week in order to confirm the steady state for the different parameters, and to ensure the stability of the system and the different chemicalphysical variables. Under these conditions the unit proved to be stable [96-105]. According to what was observed in the various tests before performing the inoculations, the variations were within the defined limits, and in particular: recirculation water temperature: $>30{ }^{\circ} \mathrm{C}$ (maximum variation interval observed following injection/ removal: $30-36^{\circ} \mathrm{C}$ ); chlorine dioxide: $0.2 \mathrm{ppm}$ (maximum variation interval observed: 0.19-0.40); conductivity: 330-338 $\mu$; chlorites: $0.230-0.707 \mu \mathrm{g} / \mathrm{L}$ (under storage conditions due to absence of make-up and maintenance of the recirculation for 7 days in a total volume of about 50 Liters). The specific conditions reported at the time of inoculation with Legionella pneumophila were water temperature in the system: 36 and $34 \mathrm{C}^{\circ}$; ClO2: 0.241 and 0.251 ppm, in full agreement with what was previously observed.

\section{Results}

The tests carried out showed disinfectant efficacy on the various bacterial species already from the samples taken within 5 minutes (T5) of exposition to the disinfectant (T0), with a reduction near 100\% (>99.999\%) within 30 minutes. In particular:

1) E. faecalis showed a $>99 \%$ reduction already within the first 5 minutes (Figures 2A \& 2B).

2) E. coli showed a $>99 \%$ reduction already within the first 5 minutes according to molecular data, even if in this experimental test the value could not be estimated as accurately in MPN, so it is prudentially reported the maximum value hypothesized. In any case, the reduction is confirmed $>99 \%$ at 30 ' (Figures $3 A$ \& 3B).

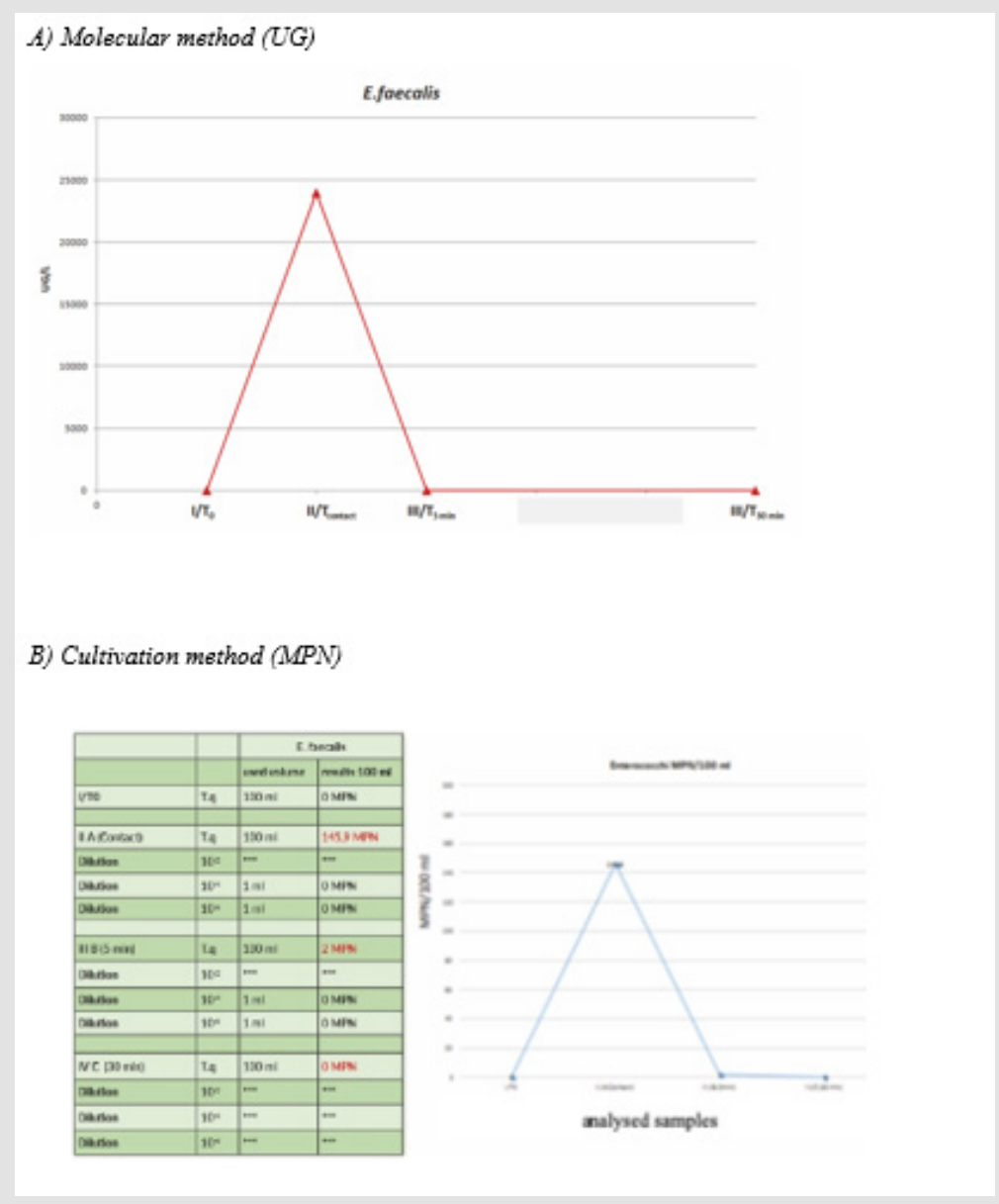

Figure 2: Reduction of microbial load: E. faecalis.

Note: $\mathrm{T}_{0}$ : situation in the system at zero time; $\mathrm{T}_{\text {contact }}$ : analysis performed on sample taken immediately after inoculation; $\mathrm{T}_{5}$ : analysis performed on sample taken after 5 minutes; $\mathrm{T}_{30}$ : analysis performed on sample taken after 30 minutes. 


\section{A) Molecular method (UG)}

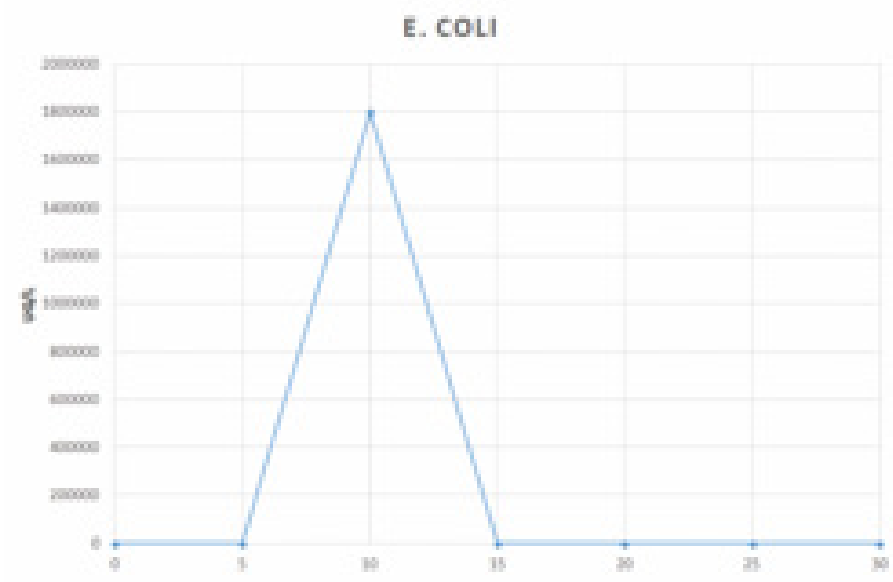

B) Cultivation method (MPN)

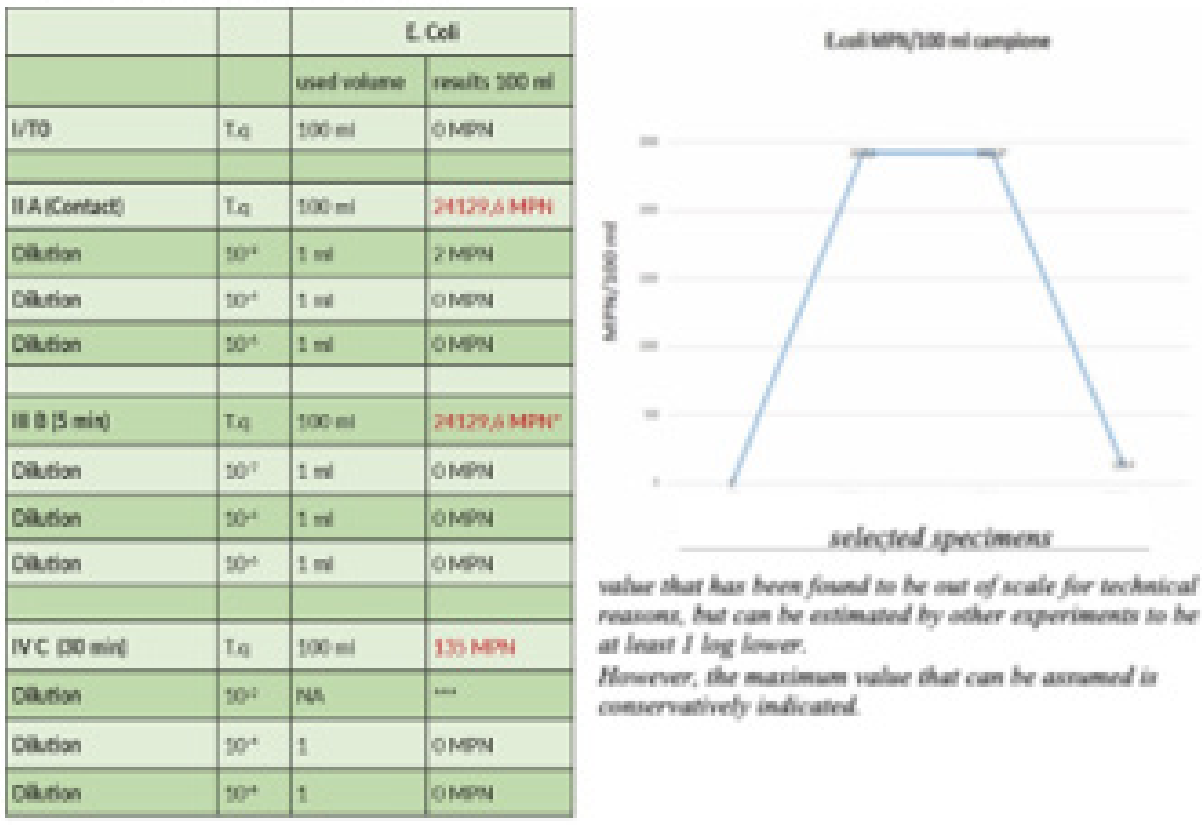

Figure 3: Reduction of microbial charge: E. coli.

Note: $\mathrm{T}_{0}$ : situation in the system at zero time; $\mathrm{T}_{\text {contact }}$ : analysis performed on sample taken immediately after inoculation; $\mathrm{T}_{5}$ : analysis performed on sample taken after 5 minutes; $T_{30}$ : analysis performed on sample taken after 30 minutes. (NB: the data in UG on E. Coli refer to a validity threshold $<33 \mathrm{CT}$ as the tests have been performed using recombinant Taq. In addition, the MPN value at $T_{5}$ is overestimated).

3) The total microbial charge, including the biofilm component in the supply water and in the system, is reduced by more than $99 \%$ following the activation of the disinfectant equipment able to produce Chlorine Dioxide. This observation is demonstrated both by the cultivation tests (Figure $4 \mathrm{~A}$ ) and by a molecular test which is able to significantly identify both the indicators used and the complexity of the bacterial microflora present in its different bacterial species (Figure 4B). In addition, the integration (Figure 4A) of a further experiment carried out over a longer period (2-3 months) and aimed at verifying the abatement capacity of the microflora present in the water inlet of the system is also reported. The disinfectant action appears effective and active on different bacterial species. 


\section{A) Cultivation method (CFU)}

\begin{tabular}{|c|c|c|c|}
\hline Somple & Oakition & values & cruim \\
\hline v10 & $\tau / 4$ & $1 \mathrm{nt}$ & 1940 MPF \\
\hline 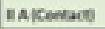 & $\tau_{4}$ & $1=1$ & $\$ \$ 0000$ \\
\hline Detrition & $10^{\prime}$ & $\ldots$ & \\
\hline Delution & $10^{4}$ & $1 \neq t$ & $a$ \\
\hline Divion & tot & $1 \neq i$ & e \\
\hline 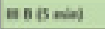 & Ta & $1 \approx t$ & 2000 \\
\hline Detrion & $10^{\circ}$ & $\cdots$ & \\
\hline Dutrom & $50^{*}$ & $10 t$ & . \\
\hline Datom & tet & $1 \times t$ & - \\
\hline 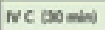 & Ta & 101 & 39 \\
\hline Dutition & 104 & $\ldots$ & \\
\hline Devtion & $10^{*}$ & I & - \\
\hline Dethion & tot & 1 & 6 \\
\hline
\end{tabular}

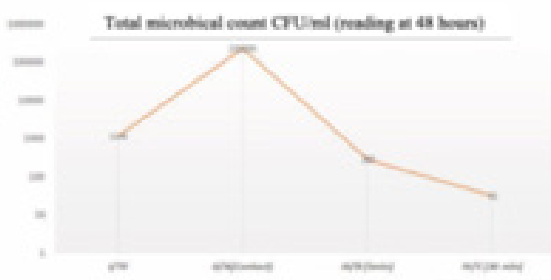

B) Cultivation method (MPN)

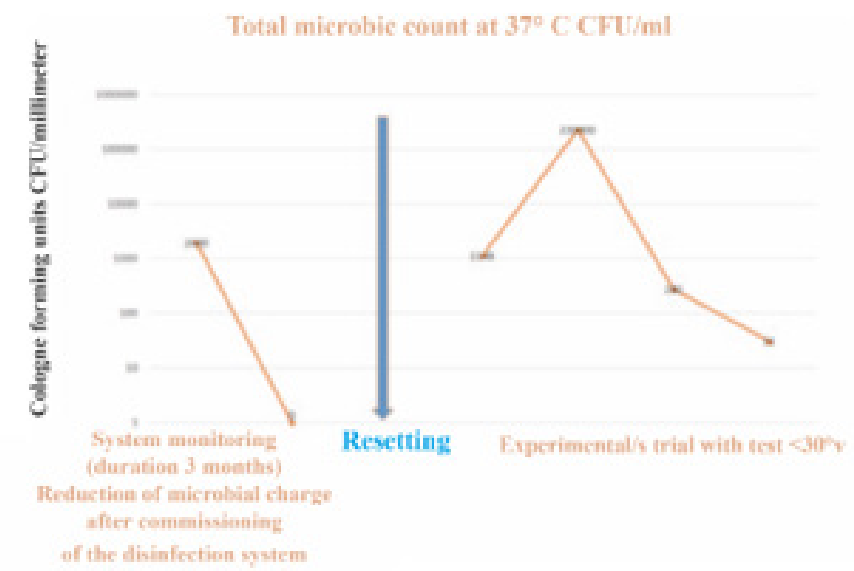

Figure 4.

In addition, the 2018 trial showed disinfectant efficacy on Legionella pneumophila, with a killing rate close to $100 \%$ (>99.999\%) within 30 minutes. Even after repeated contamination, the system proved to be able to demonstrate the maintenance of disinfectant efficacy over time, even after 1 hour and 20 hours after subsequent inoculations of the order of billions of viable bacterial cells. The pilot plant had previously been balanced and the various parameters kept under control for at least one week before the contamination experiment was carried out. The temperature of the implant was maintained at conditions above $30{ }^{\circ} \mathrm{C}$ to promote the survival of Legionella by performing the contaminations at 36 and $34{ }^{\circ} \mathrm{C}$. During the experiment, the values of Chlorine Dioxide were observed to be kept within the prescribed limits, i.e. in particular between 0,242 and 0,251 ppm. The values reported for Chlorites also remained within acceptable limits and in any case always $<0,7$ $\mu \mathrm{g} / \mathrm{L}$, even in conditions of prolonged accumulation in the absence of dilution for reintegration (Appendix 2). The killing of Legionella pneumophila was demonstrated not only by using the traditional procedures provided for in the guidelines, but also in parallel with innovative methods based on defined substrate technology, fully confirming the disinfectant efficacy of $\mathrm{ClO}_{2}$, and in particular the complete elimination of viable cells of Legionella within $30^{\prime}$ of inoculation.

The presence of bacteria in the implant was also evaluated by molecular methods, further validating the microbial load, and demonstrating the presence of dead bacterial cells following the treatment in question (>108UG/L) (Figure 5). All these observations allow sustaining with high relevance the disinfectant efficacy on Legionella pneumophila of the Chlorine Dioxide released inside the pilot unit in question. 


\section{Test 1:}

Test 2:
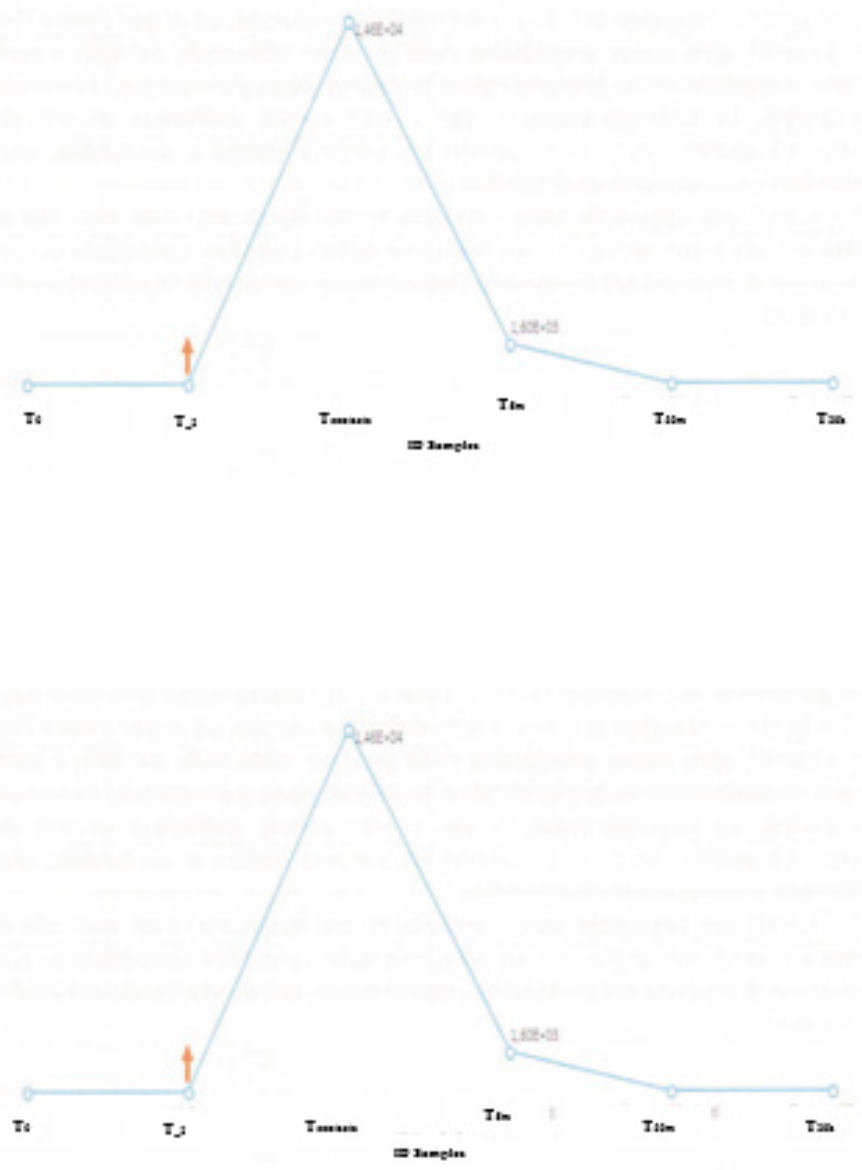

Figure 5: Reduction of microbial load: Legionella pneumophila.

Note: $\mathrm{T}_{0}$ : situation in the system at zero time; $\mathrm{T}_{\text {contact }}$ : analysis performed on sample taken immediately after inoculation; $\mathrm{T}_{5}$ : analysis performed on sample taken after 5 minutes; $\mathrm{T}_{30}$ : analysis performed on sample taken after 30 minutes.

\section{Discussion}

The disinfection treatment in question proved effective in killing a Gram-positive bacterium (E. faecalis) and a Gram-negative bacterium (E. coli), both indicators of faecal contamination. However, the disinfectant action is also evident on the total bacterial count as it can act on several other microbial species, as shown by the application of both traditional and molecular cultivation methods based on bacterial DNA analysis. The indication of disinfectant efficacy, even on a wider range of environmental species present in aquatic microflora or biofilm, suggests the applicability of this treatment also for the clean-up of installations or for the processing of supply waters that do not fully satisfy the essential requirements of potability. Among these micro-organisms that can be found in water systems there may be some pathogens, including enterobacteria, or species belonging to the family of Legionellaceae. The pilot plant designed and developed could be a model for further investigations, especially in the light of the experimental protocols adapted for exposition, sampling, analysis, even in the presence of multiple contaminations [106-114]. The treatment system based on the action of the chlorine dioxide generator in the study shows an effective disinfectant action. The results reported are particularly significant, therefore, not only considering the observations acquired, but also considering the controlled conditions in which it was possible to perform the tests of effectiveness of the disinfectant treatment, simulating conditions verifiable within a water system.

The disinfection intervention has been more effective in killing Legionella pneumophila. This observation is in addition to the previous ones, allowing to acquire information strongly significant in terms of disinfectant effectiveness even after particularly high contamination (>109 UFC) and supporting a clear disinfectant action also for other microbial species and, more generally, for the reduction of the total bacterial charge. It is important to note that, 
although some initial experimental conditions could adversely affect 1 the reported values, Chloritis remained within acceptable limits. In the light of the various information acquired, the treatment system based on the action of Chlorine Dioxide from the generator, used in the pilot plant, shows an effective disinfectant action against Legionella and a particularly valid approach to use because it is based on real-time monitoring of various parameters through an integrated and automated management philosophy. Note, as a further remarkable aspect, that also the results reported for Chlorites remained within the acceptable limits, although the starting limits at the time of the experimental inoculation trials of the bacterium were already relatively high due to the introduction of $\mathrm{ClO}_{2}$, kept at steady state for more than a week in the absence of reintegration of the introduction of disinfectant automatically and also following the inoculation with organic material, the volume in scale of the installation and the inevitable accumulation due to the closed system of recirculation of the installation in size (Appendix 3).

In consideration of the different information acquired, the treatment system based on the action of Chlorine Dioxide and studied through the pilot unit previous described, therefore, shows an effective disinfectant action against Legionella and a particularly valid approach of use, as it is based on the real-time monitoring of various parameters through an integrated and atomized management of the disinfection system. For applications on extended installations of different types, not only in terms of safety but also quality, the proposed water treatment policy is therefore effective and promising. The pilot installation has proved to be a stable and modular system that merits further study and technical-scientific development. The results reported for Legionella are particularly significant not only in the context of the various observations collected, but also in consideration of the controlled conditions in which it was possible to perform tests on the effectiveness of the disinfectant treatment, simulating conditions that could be verified inside a water system.

In conclusion, regarding the efficacy profile of the analyzed $\mathrm{ClO}_{2}$ generator, an interesting decontamination activity has been observed even in the case of water, which for various reasons does not present suitable characteristics of potability and an important and more than significant possible decontamination activity against different microbial agents, such as yeasts/fungi and bacteria, among the latest we can indicate as frequent contaminants Pseudomanas aeruginosa, E. coli, Legionellaceae.

A more than relevant and significant activity has been demonstrated towards Legionella pneumophila under measurable conditions of stressed system, through analytical determinations, also of an extremely innovative and technologically advanced type, allowing the extrapolation of the results obtained also for other identical equipment but with superior functional capacities. From a careful examination of the experimental results and of the technicalscientific literature on the subject and, considering the reference legislation of the sector already mentioned, the treatment of disinfection of the water system that uses the mentioned generator of $\mathrm{ClO}_{2}$ qualifies among the safety measures to be implemented for the risk of infectious agents and is considered to comply with the provisions of the current Italian and Community legislation, i.e. Legislative Decree 81/2008 and subsequent amendments and integrations,(transposition of EU Directives on hygiene and safety at work), with particular reference to Title X (transposition of Directive 54/2000 EC) and Title I (transposition of Directive 391/89 EC).

\section{References}

1. D.lgs. 9 aprile 2008 , n. 81 coordinated text with the D.Lgs. $3^{\text {rd }}$ august 2009, n. 106. Text on health and safety at work. Application of the article 1 of law of $3^{\text {rd }}$ august $2007, n .123$ on health and safety protection in the workplace. (Gazzetta Ufficiale n. 101 del 30 aprile 2008 - Ordinary suppl. n. 108) (supplementary and corrective measures: Gazzetta Ufficiale n. 180 of $5^{\text {th }}$ august 2009 - Ordinary suppl. n. 142/L) Rev.april 2019).

2. European Directive 89/391/EEC of the Council of $12^{\text {th }}$ of june 1989 , concerning the introduction of measures to encourage improvements in the safety and health of workers at work Gazzetta ufficiale n. L 183 of 29/06/1989 pag. $0001-0008$.

3. European Parliament's Directive 2000/54/EEC of $18^{\text {th }}$ of September 2000 concerning workers protection in workplace against risks related to exposure to biological agents at work (seventh directive in particular for art. $16^{\text {th }}$, paragraph 1, of directive 89/391/EEC). G.U. of European Community n. L 262/21 del 17/10/2000.

4. Agarwal S, Abell V, File TM (2017) Nosocomial (Health Care-Associated) Legionnaire's Disease. Infect Dis Clin North Am 31(1): 155-165.

5. Ambrose J, Hampton LM, Fleming Dutra KE, Marten C, Mc Clusky C, et al (2014) Large outbreak of Legionnaires' disease and Pontiac fever at a military base. Epidemiol Infect 142(11): 2336-2346.

6. Amodeo MR, Murdoch DR, Pithie AD (2010) Legionnaires' disease caused by Legionella longbeachae and Legionella pneumophila: comparison of clinical features, host-related risk factors, and outcomes. Clin Microbiol Infect 16(9): 1405-1407.

7. Banderet F, Blaich A, Soleman E, Gaia V, Osthoff M (2017) Septic arthritis due to Legionella cincinnatiensis: case report and review of the literature. Infection 45(4): 551-555.

8. Barigou M, Cavalie L, Daviller B, Dubois D, Mantion B, et al. (2015) Isolation on Chocolate Agar Culture of Legionella pneumophila Isolates from Subcutaneous Abscesses in an Immunocompromised Patient. J Clin Microbiol 53(11): 3683-3685.

9. Bellew S, Grijalva CG, Williams DJ, Anderson EJ, Wunderink RG, et al. (2019) Pneumococcal and Legionella Urinary Antigen Tests in Community-acquired Pneumonia: Prospective Evaluation of Indications for Testing. Clin Infect Dis 68(12): 2026-2033.

10. Benedict KM, Reses H, Vigar M, Roth DM, Roberts VA, et al. (2017) Surveillance for Waterborne Disease Outbreaks Associated with Drinking Water - United States, 2013-2014. MMWR Morb Mortal Wkly Rep 66(44): 1216-1221.

11. Benvenuti F, Lombardi R (2000) ISPESL Guidelines. Biological risk: application procedure for risk assessment and planning of prevention and protection interventions. Ann Ig 12(4 Suppl 2): 329-360.

12. Blázquez Garrido RM, Espinosa Parra FJ, Alemany Francés L, Ramos Guevara RM, Sánchez Nieto JM, et al. (2005) Antimicrobial chemotherapy for Legionnaires disease: levofloxacin versus macrolides. Clin Infect Dis 40(6): 800-806.

13. Bopp LH, Baltch AL, Ritz WJ, Michelsen PB, Smith RP (2011) Activities of tigecycline and comparators against Legionella pneumophila and 
Legionella micdadei extracellularly and in human monocyte-derived macrophages. Diagn Microbiol Infect Dis 69(1): 86-93.

14. Bryner B, Miskulin J, Smith C, Cooley E, Grams R, et al. (2014) Extracorporeal life support for acute respiratory distress syndrome due to severe Legionella pneumonia. Perfusion 29(1): 39-43.

15. Burke PT, Shah R, Thabolingam R, Saba S (2009) Suspected Legionellainduced perimyocarditis in an adult in the absence of pneumonia: a rare clinical entity. Tex Heart Inst J 36(6): 601603.

16. Burnsed LJ, Hicks LA, Smithee LM, Fields BS, Bradley KK, et al. (2007) A large, travel-associated outbreak of legionellosis among hotel guests: utility of the urine antigen assay in confirming Pontiac fever. Clin Infect Dis 44(2): 222-228.

17. Cecchini J, Tuffet S, Sonneville R, Fartoukh M, Mayaux J, et al. (2017) Antimicrobial strategy for severe community-acquired legionnaires' disease: a multicentre retrospective observational study. J Antimicrob Chemother 72(5): 1502-1509.

18. Centers for Disease Control and Prevention (CDC) (2018) Considerations for Public Hot Tub Operators. Legionella (Legionnaires' Disease and Pontiac Fever): Water System Maintenance.

19. Cervero Aragó S, Rodríguez Martínez S, Puertas Bennasar A, Araujo RM (2015) Effect of Common Drinking Water Disinfectants, Chlorine and Heat, on Free Legionella and Amoebae-Associated Legionella. PLoS One 10(8): e0134726.

20. Charles M, Johnson E, Macyk Davey A, Henry M, Nilsson JE, et al. (2013) Legionella micdadei brain abscess. J Clin Microbiol 51(2): 701-704.

21. Chen DJ, Procop GW, Vogel S, Yen Lieberman B, Richter SS (2015) Utility of PCR, Culture, and Antigen Detection Methods for Diagnosis of Legionellosis. J Clin Microbiol 53(11): 3474-3477.

22. Chidiac C, Che D, Pires Cronenberger S, Jarraud S, Campèse $C$, et al (2012) Factors associated with hospital mortality in communityacquired legionellosis in France. Eur Respir J 39(4): 963-970.

23. Chitasombat MN, Ratchatanawin N, Visessiri Y (2018) Disseminated extrapulmonary Legionella pneumophila infection presenting with panniculitis: case report and literature review. BMC Infect Dis 18(1) 467.

24. Correia AM, Ferreira JS, Borges V, Nunes A, Gomes B, et al. (2016) Probable Person-to-Person Transmission of Legionnaires' Disease. N Engl J Med 374(5): 497-498.

25. Cristovam E, Almeida D, Caldeira D, Ferreira JJ, Marques T (2017) Accuracy of diagnostic tests for Legionnaires' disease: a systematic review. J Med Microbiol 66(4): 485-489.

26. Damásio AF, Rodrigues L, Miranda L, Coelho P, Banazol N, et al. (2014) Fulminant myocarditis caused by Legionella pneumophila: case report. Rev Port Cardiol 33(3): 185.e1-185.e5.

27. David S, Afshar B, Mentasti M, Ginevra C, Podglajen I, et al. (2017) Seeding and Establishment of Legionella pneumophila in Hospitals: Implications for Genomic Investigations of Nosocomial Legionnaires Disease. Clin Infect Dis 64(9):1251-1259.

28. Demirjian A, Lucas CE, Garrison LE, Kozak Muiznieks NA, States S, et al. (2015) The importance of clinical surveillance in detecting legionnaires' disease outbreaks: a large outbreak in a hospital with a Legionella disinfection system-Pennsylvania, 2011-2012. Clin Infect Dis 60(11): 1596-1602.

29. Den Boer JW, Nijhof J, Friesema I (2006) Risk factors for sporadic community-acquired Legionnaires' disease. A 3-year national casecontrol study. Public Health 120(6): 566-571.

30. Diederen BM (2008) Legionella spp. and Legionnaires' disease. J Infect 56(1): 1-12.

31. Dominguez A, Alvarez J, Sabria M, Carmona G, Torner N, et al. (2009) Factors influencing the case-fatality rate of Legionnaires' disease. Int J Tuberc Lung Dis 13(3): 407-412.
32. Dooling KL, Toews KA, Hicks LA, Garrison LE, Bachaus B, et al. (2015) Active Bacterial Core Surveillance for Legionellosis - United States, 2011-2013. MMWR Morb Mortal Wkly Rep 64(42): 1190-1193.

33. Dunbar LM, Khashab MM, Kahn JB, Zadeikis N, Xiang JX, et al. (2004) Efficacy of 750-mg, 5-day levofloxacin in the treatment of communityacquired pneumonia caused by atypical pathogens. Curr Med Res Opin 20(4): 555-563.

34. Bennet JE, Dolin R, Blaser MJ (2015) Mandell, Douglas, and Bennett's Principles and Practice of Infectious Diseases. ( $8^{\text {th }}$ Edn.), Elsevier, Pennsylvania, USA.

35. Edelstein PH, Weiss WJ, Edelstein MA (2003) Activities of tigecycline (GAR-936) against Legionella pneumophila in vitro and in guinea pigs with L. pneumophila pneumonia. Antimicrob Agents Chemother 47(2): 533-540.

36. Ehret KM, Chamberlain AT, Berkelman RL, Fridkin SK (2018) Preventing hospital-acquired Legionnaires' disease: A snapshot of clinical practices and water management approaches in US acute-care hospitals. Infect Control Hosp Epidemiol 39(12):1470-1472.

37. Eliakim Raz N, Robenshtok E, Shefet D, Gafter Gvili A, Vidal A, et al. (2012) Empiric antibiotic coverage of atypical pathogens for communityacquired pneumonia in hospitalized adults. Cochrane Database Syst Rev 2012(9): CD004418.

38. Eljaaly K, Alshehri S, Aljabri A, Abraham I, Mohajer MA, et al. (2017) Clinical failure with and without empiric atypical bacteria coverage in hospitalized adults with community-acquired pneumonia: a systematic review and meta-analysis. BMC Infect Dis 17: 385.

39. Fernández JA, López P, Orozco D, Merino J (2002) Clinical study of an outbreak of Legionnaire's disease in Alcoy, Southeastern Spain. Eur J Clin Microbiol Infect Dis. 21(10):729-735.

40. Fernández Cruz A, Marín M, Castelo L, Usubillaga R, Martín Rabadán (2011) Legionella micdadei, a new cause of prosthetic joint infection. J Clin Microbiol 49(9):3409-3410.

41. Fernández Sabé N, Rosón B, Carratalà J, Dorca J, Manresa F (2003) Clinical diagnosis of Legionella pneumonia revisited: evaluation of the Community-Based Pneumonia Incidence Study Group scoring system. Clin Infect Dis 37(4): 483-489.

42. Fiumefreddo R, Zaborsky R, Haeuptle J, Christ Crain M, Trampuz A, et al. (2009) Clinical predictors for Legionella in patients presenting with community-acquired pneumonia to the emergency department. BMC Pulm Med 9: 4.

43. Flendrie M, Jeurissen M, Franssen M, Kwa D, Klaassen C, et al. (2011) Septic arthritis caused by Legionella dumoffii in a patient with systemic lupus erythematosus-like disease. J Clin Microbiol 49(2): 746-749.

44. Forsberg KJ, Patel S, Wencewicz TA, Dantas G (2015) The Tetracycline Destructases: A Novel Family of Tetracycline-Inactivating Enzymes. Chem Biol 22(7): 888-897.

45. Franco Garcia A, Varughese TA, Lee YJ, Papanicolaou G, Rosenblum MK, et al. (2017) Diagnosis of Extrapulmonary Legionellosis in Allogeneic Hematopoietic Cell Transplant Recipients by Direct 16S Ribosomal Ribonucleic Acid Sequencing and Matrix-Assisted Laser Desorption/ Ionization Time-of-Flight Mass Spectrometry. Open Forum Infect Dis 4(3): ofx140.

46. Fukuta Y, Yildiz Aktas IZ, William Pasculle A, Veldkamp PJ (2012) Legionella micdadei prosthetic valve endocarditis complicated by brain abscess: case report and review of the literature. Scand J Infect Dis 44(6): 414-418.

47. Gacouin A, Le Tulzo Y, Lavoue S, Camus C, Hoff J, et al. (2002) Severe pneumonia due to Legionella pneumophila: prognostic factors, impact of delayed appropriate antimicrobial therapy. Intensive Care Med 28(6): 686-691.

48. Garcia Vidal C, Sanchez Rodriguez I, Simonetti AF, Burgos J, Viasus D, et al. (2017) Levofloxacin versus azithromycin for treating legionella 
pneumonia: a propensity score analysis. Clin Microbiol Infect 23(9): 653-658.

49. Gilbert DN (2017) Role of Procalcitonin in the Management of Infected Patients in the Intensive Care Unit. Infect Dis Clin North Am 31(3): 435453.

50. Grau S, Antonio JM, Ribes E, Salvadó M, Garcés JM, et al. (2006) Impact of rifampicin addition to clarithromycin in Legionella pneumophila pneumonia. Int J Antimicrob Agents 28(3): 249-252.

51. Gubler JG, Schorr M, Gaia V, Zbinden R, Altwegg M (2001) Recurrent soft tissue abscesses caused by Legionella cincinnatiensis. J Clin Microbiol 39(12): 4568-4570.

52. Guy SD, Worth LJ, Thursky KA, Francis PA, Slavin MA (2011) Legionella pneumophila lung abscess associated with immune suppression. Intern Med J 41(10): 715-721.

53. Han JH, Nguyen JC, Harada S, Baddour LM, Edelstein PH (2010) Relapsing Legionella pneumophila cellulitis: a case report and review of the literature. J Infect Chemother 16(6): 439-442.

54. Hayashi M, Kuraishi H, Masubuchi T, Furihata K, Aida Y, et al. (2013) A Fatal Case of Relapsing Pneumonia Caused by Legionella pneumophila in a Patient with Rheumatoid Arthritis After Two Injections of Adalimumab. Clin Med Insights Case Rep 6: 101-106.

55. Health and Safety Executive (2018) Legionella and Legionnaire's disease.

56. Htwe TH, Khardori NM (2017) Legionnaire's Disease and Immunosuppressive Drugs. Infect Dis Clin North Am 31(1): 29-42.

57. Ingram JG, Plouffe JF (1994) Danger of sputum purulence screens in culture of Legionella species. J Clin Microbiol 32(1): 209-210.

58. Isenman $\mathrm{H}$, Anderson T, Chambers ST, Podmore RG, Murdoch DR (2018) Antimicrobial susceptibilities of clinical Legionella longbeachae isolates. J Antimicrob Chemother 73(4): 1102-1104.

59. Isenman HL, Chambers ST, Pithie AD, Mac Donald SLS, Hegarty JM, et al. (2016) Legionnaires' disease caused by Legionella longbeachae: Clinical features and outcomes of 107 cases from an endemic area. Respirology 21(7): 1292-1299.

60. Ishimaru N, Suzuki H, Tokuda Y, Takano T (2012) Severe Legionnaires disease with pneumonia and biopsy-confirmed myocarditis most likely caused by Legionella pneumophila serogroup 6. Intern Med 51(22): 3207-3212

61. Ito A, Ishida T, Washio Y, Yamazaki A, Tachibana H (2017) Legionella pneumonia due to non-Legionella pneumophila serogroup 1: usefulness of the six-point scoring system. BMC Pulm Med 17:211.

62. Jain S, Self WH, Wunderink RG, Fakhran S, Balk R, et al. (2015) Community-Acquired Pneumonia Requiring Hospitalization among U.S. Adults. N Engl J Med 373(5): 415-427.

63. Jespersen S, Søgaard OS, Schønheyder HC, Fine MJ, Ostergaard L (2010) Clinical features and predictors of mortality in admitted patients with community- and hospital-acquired legionellosis: a Danish historical cohort study. BMC Infect Dis 10:124.

64. Jonas D, Engels I, Daschner FD, Frank U (2000) The effect of azithromycin on intracellular Legionella pneumophila in the Mono Mac 6 cell line at serum concentrations attainable in vivo. J Antimicrob Chemother 46(3): 385-390.

65. Just SA, Knudsen JB, Uldum SA, Holt HM (2012) Detection of Legionella bozemanae, a new cause of septic arthritis, by PCR followed by specific culture. J Clin Microbiol 50(12): 4180-4182.

66. Kenagy E, Priest PC, Cameron CM, Smith D, Scott P, et al. (2017) Risk Factors for Legionella longbeachae Legionnaires' Disease, New Zealand. Emerg Infect Dis 23(7): 1148-1154.

67. Lanternier F, Tubach F, Ravaud P, Salmon D, Dellamonica P, et al. (2013) Incidence and risk factors of Legionella pneumophila pneumonia during anti-tumor necrosis factor therapy: a prospective French study. Chest 144(3): 990-998.

68. Leggieri N, Gouriet F, Thuny F, Habib G, Raoult D, et al. (2012) Legionella longbeachae and endocarditis. Emerg Infect Dis 18: 95-97.

69. Levcovich A, Lazarovitch T, Moran Gilad J, Peretz C, Yakunin E, et al. (2016) Complex clinical and microbiological effects on Legionnaires' disease outcone; A retrospective cohort study. BMC Infect Dis 16: 75

70. Lim WS, Baudouin SV, George RC, Hill AT, Jamieson C, et al. (2009) BTS guidelines for the management of community acquired pneumonia in adults: update 2009. Thorax. 64 Suppl 3: iii1-55.

71. Lim WS, Woodhead M (2011) British Thoracic Society. British Thoracic Society adult community acquired pneumonia audit 2009/10. Thorax 66(6): 548 .

72. Lin YE, Stout JE, Yu VL (2011) Controlling Legionella in hospital drinking water: an evidence-based review of disinfection methods. Infect Control Hosp Epidemiol 32(2): 166-173.

73. Lombardi R, Curini R (2009) ISPESL Linee Guida per gli interventi di prevenzione relativi alla sicurezza e all'igiene del lavoro nel Reparto Operatorio.

74. Loridant S, Lagier JC, La Scola B (2011) Identification of Legionella feeleii cellulitis. Emerg Infect Dis17(1): 145-146.

75. Mandell LA, Wunderink RG, Anzueto A, Bartlett JG, Campbell GD, et al. (2007) Infectious Diseases Society of America/American Thoracic Society consensus guidelines on the management of communityacquired pneumonia in adults. Clin Infect Dis 44(Suppl 2): S27-72.

76. Marchello C, Dale AP, Thai TN, Han DS, Ebell MK (2016) Prevalence of Atypical Pathogens in Patients With Cough and Community-Acquired Pneumonia: A Meta-Analysis. Ann Fam Med 14(6): 552-566.

77. Marchesi I, Marchegiano P, Bargellini A, Cencetti S, Frezza G, et al. (2011) Effectiveness of different methods to control legionella in the water supply: ten-year experience in an Italian university hospital. J Hosp Infect 77(1): 47-51

78. Maze MJ, Slow S, Cumins AM, Boon K, Goulter P, et al. (2014) Enhanced detection of Legionnaires' disease by PCR testing of induced sputum and throat swabs. Eur Respir J 43(2): 644-646.

79. Mc Clelland MR, Vaszar LT, Kagawa FT (2004) Pneumonia and osteomyelitis due to Legionella longbeachae in a woman with systemic lupus erythematosus. Clin Infect Dis 38(10): e102-106.

80. McClung RP, Roth DM, Vigar M, Roberts VA, Kahler AM, et al. (2017) Waterborne Disease Outbreaks Associated With Environmental and Undetermined Exposures to Water - United States, 2013-2014. MMWR Morb Mortal Wkly Rep 66(44): 1222-1225.

81. Mentasti M, Fry NK, Afshar B, Palepou Foxley C, Naik FC, et al. (2012) Application of Legionella pneumophila-specific quantitative real-time PCR combined with direct amplification and sequence-based typing in the diagnosis and epidemiological investigation of Legionnaires' disease. Eur J Clin Microbiol Infect Dis 31(8): 2017-2028.

82. Mills GD, Oehley MR, Arrol B (2005) Effectiveness of beta lactam antibiotics compared with antibiotics active against atypical pathogens in non-severe community acquired pneumonia: meta-analysis. BMJ 330(7489): 456.

83. Miyashita N, Horita N, Higa F, Aoki Y, Kikuchi T, et al. (2018) Diagnostic predictors of Legionella pneumonia in Japan. J Infect Chemother 24(3): 159-163.

84. Muder RR, Yu VL (2002) Infection due to Legionella species other than L. pneumophila. Clin Infect Dis 35(8): 990-998.

85. Murdoch DR, Podmore RG, Anderson TP, Barratt K, Maze MJ, et al. (2013) Impact of routine systematic polymerase chain reaction testing on case finding for Legionnaires' disease: a pre-post comparison study. Clin Infect Dis 57(9): 1275-1281. 
86. Musher DM, Abers MS, Bartlett JG (2017) Evolving Understanding of the Causes of Pneumonia in Adults, With Special Attention to the Role of Pneumococcus. Clin Infect Dis 65(10): 1736-1744.

87. Mykietiuk A, Carratalà J, Fernández Sabé N, Dorca J, Verdaguer R, et al. (2005) Clinical outcomes for hospitalized patients with Legionella pneumonia in the antigenuria era: the influence of levofloxacin therapy. Clin Infect Dis 40(6): 794-799.

88. National Institute for Health and Care Excellence (2019) Pneumonia in adults: Diagnosis and management.

89. Noah MA, Ramachandra G, Hickey MM, Jenkins DR, Harvey CJ, et al. (2013) Extracorporeal membrane oxygenation and severe acute respiratory distress secondary to Legionella: 10 year experience. ASAIO J 59(3): 328-330.

90. Padrnos LJ, Blair JE, Kusne S, Di Caudo DJ, Mikhael JR (2014) Cutaneous legionellosis: case report and review of the medical literature. Transpl Infect Dis 16(2): 307-314.

91. Park J, Gasparrini AJ, Reck MR, Symister CT, Elliott JL, et al. (2017) Plasticity, dynamics, and inhibition of emerging tetracycline resistance enzymes. Nat Chem Biol 13(7): 730-736.

92. Patel MC, Levi MH, Mahadevi P, Nana M, Merav AD, et al. (2005) L. micdadei PVE successfully treated with levofloxacin/valve replacement: case report and review of the literature. J Infect 51(5): e265-268.

93. Pearce MM, Theodoropoulos N, Mandel MJ, Brown E, Reed KD, et al. (2012) Legionella cardiacasp. nov., isolated from a case of native valve endocarditis in a human heart. Int J Syst Evol Microbiol 62(Pt 12): 29462954.

94. Peci A, Winter AL, Gubbay JB (2016) Evaluation and Comparison of Multiple Test Methods, Including Real-time PCR, for Legionella Detection in Clinical Specimens. Front Public Health 4: 175.

95. Perpoint T, Jamilloux Y, Descloux E, Ferry T, Chidiac C, et al. (2013) PCRconfirmed Legionella non-pneumophila meningoencephalitis. Med Mal Infect 43(1): 32-34.

96. Poirier R, Rodrigue J, Villeneuve J, Lacasse Y (2017) Early Radiographic and Tomographic Manifestations of Legionnaires' Disease. Can Assoc Radiol J 68(3):328-333.

97. Qin X, Abe PM, Weissman SJ, Manning SC (2002) Extrapulmonary Legionella micdadei infection in a previously healthy child. Pediatr Infect Dis J 21(12):1174-1176.

98. Rihs JD, Yu VL, Zuravleff JJ, Goetz A, Murder RR (1985) Isolation of Legionella pneumophila from blood with the BACTEC system: a prospective study yielding positive results. J Clin Microbiol 22(3):422424.

99. Roed T, Schønheyder HC, Nielsen H (2015) Predictors of positive or negative legionella urinary antigen test in community-acquired pneumonia. Infect Dis (Lond) 47(7): 484-490.

100. Roncon Albuquerque R, Vilares Morgado R, van der Heijden GJ, Ferreira Coimbra J, Mergulhão P, et al. (2019) Outcome and Management of Refractory Respiratory Failure with Timely Extracorporeal Membrane Oxygenation: Single-Center Experience With Legionella Pneumonia. J Intensive Care Med 34(4):344-350.
101. Samuel V, Bajwa AA, Cury JD (2011) First case of Legionella pneumophila native valve endocarditis. Int J Infect Dis 15(8): e576577.

102. Sanchez MC, Sebti R, Hassoun P, Mannion C, Goy AH, et al. (2013) Osteomyelitis of the patella caused by Legionella anisa. J Clin Microbiol 51(8): 2791-2793.

103. Schaumann R, Pönisch W, Helbig JH, Hegenbart U, Ackermann G, et al. (2001) Pericarditis after allogeneic peripheral blood stem cell transplantation caused by Legionella pneumophila (non-serogroup 1). Infection 29(1): 51-53.

104. Self WH, Balk RA, Grijalva CG, Williams DJ, Zhu Y, et al. (2017) Procalcitonin as a Marker of Etiology in Adults Hospitalized With Community-Acquired Pneumonia. Clin Infect Dis 65(2): 183-190.

105. Shimada T, Noguchi Y, Jackson JL, Miyashita J, Hayashino Y, et al. (2009) Systematic review and metaanalysis: urinary antigen tests for Legionellosis. Chest 136(6): 1576-1585.

106. Sivagnanam S, Podczervinski S, Butler Wu SM, Hawkins V, Stednick $\mathrm{Z}$, et al. (2017) Legionnaires' disease in transplant recipients: A 15year retrospective study in a tertiary referral center. Transpl Infect Dis $19(5)$.

107. Sopena N, Force L, Pedro Botet ML, Barrufet P, Sauca G, et al. (2007) Sporadic and epidemic community legionellosis: two faces of the same illness. Eur Respir J 29(1): 138-142.

108. Straus WL, Plouffe JF, File TM, Lipman HB, Hackman BH, et al. (1996) Risk factors for domestic acquisition of legionnaires disease. Ohio legionnaires Disease Group. Arch Intern Med 156(15): 1685-1692.

109. Tan MJ, Tan JS, Hamor RH, File TM, Breiman RF (2000) The radiologic manifestations of Legionnaire's disease. The Ohio Community-Based Pneumonia Incidence Study Group. Chest 117(2): 398-403.

110. Thurneysen C, Boggian K (2014) Legionella pneumophila serogroup 1 septic arthritis with probable endocarditis in an immunodeficient patient. J Clin Rheumatol 20(5): 297-298.

111. Tubach F, Ravaud P, SalmonCéron D, Petitpain N, Brocq O, et al. (2006)Emergence of Legionella pneumophila pneumonia in patients receiving tumor necrosis factor-alpha antagonists. Clin Infect Dis 43(10): e95-100.

112. Viasus D, Di Yacovo S, GarciaVidal C, Verdaguer R, Manresa F, et al. (2013) Community-acquired Legionella pneumophila pneumonia: a single-center experience with 214 hospitalized sporadic cases over 15 years. Medicine (Baltimore) 92(1): 51-60.

113. Von Baum H, Ewig S, Marre R, Suttorp N, Gonschior S, et al. (2008) Community-acquired Legionella pneumonia: new insights from the German competence network for community acquired pneumonia. Clin Infect Dis 46(9): 1356-1364.

114. Yu VL, Plouffe JF, Pastoris MC, Stout JE, Schousboe M, et al. (2002) Distribution of Legionella species and serogroups isolated by culture in patients with sporadic community-acquired legionellosis: an international collaborative survey. J Infect Dis 186(1): 127-128. 
ISSN: 2574-1241

DOI: 10.26717/BJSTR.2020.32.005235

Roberto Lombardi. Biomed J Sci \& Tech Res

(c) (P) This work is licensed under Creative

Submission Link: https://biomedres.us/submit-manuscript.php

$\begin{array}{ll}\text { BIOMEDICAL } & \text { Assets of Publishing with us } \\ \text { RESEARCHES } & \text { - Global archiving of articles } \\ \text { - Immediate, unrestricted online access } \\ \text { - Rigorous Peer Review Process }\end{array}$

